\title{
The Xiaojiashan Tungsten deposit in the Barkol district, Xinjiang, China: geological features and ore-forming fluid composition
}

\author{
Yunfei Zhou ${ }^{1, a}$, Jiuhua $\mathrm{Xu}^{1}$ and Lihua Shan ${ }^{2}$ \\ ${ }^{1}$ University of Science and Technology Beijing, Beijing, China \\ ${ }^{2}$ Beijing Sinotech Mineral Exploration Co.,Ltd.,Beijing, China
}

\begin{abstract}
The Xiaojiashan Tungsten deposit is located in Barkol district, Xinjiang. The ore bodies occur in the Hercynian granite intrusions and contact between the intrusion and wallrock which consists of the second lithologic section of the first Sub-Formation in Middle Devonian Dananhu Formation $\left(\mathrm{D}_{2} d_{1}{ }^{2}\right)$. Quadrupole mass spectrometry reveals that fluid inclusions contain major vapor phase contents of $\mathrm{CO}_{2}, \mathrm{H}_{2} \mathrm{O}$. Meanwhile, fluid inclusions contain major liquid phase contents of $\mathrm{Cl}^{-}, \mathrm{Na}^{+}$. It can be speculated that ore-forming fluid of the Xiaojiashan wolframite deposit is characterized by a $\mathrm{CO}_{2}$-rich, low salinity, and $\mathrm{H}_{2} \mathrm{O}-\mathrm{CO}_{2}$ $\mathrm{NaCl}$ system. During ore-forming process, the magmatic water had separated from magmatic intrusions and ore-bearing complex was taken to a portion where tungsten-bearing ores could be mineralized.
\end{abstract}

Keywords: geological features; wolframite-bearing quartz vein; fluid inclusions; quadrupole mass spectrometer; Xiaojiashan.

\section{Introduction}

The Xiaojiashan Tungsten deposit, located in the Barkol district of Xinjiang, is newly found by Beijing Sinotech Mineral Exploration Co., Ltd. The ore deposit is a tungsten-quartz vein type deposit.

Tectonically, the deposit is located in the central south margin of east Junggar region. The ore bodies occur in a Hercynian granite intrusion and its contact zone with the surrounding rock of the second lithologic section of the first sub-Formation of Middle Devonian Dananhu Formation $\left(\mathrm{D}_{2} d_{1}^{2}\right)$ (Fig. 1). On the basis of geological features and petrography of the tungsten deposit rocks, this paper studies on the lithogeochemistry in Xiaojiashan tungsten deposit and discusses the hydrogeochemical differences among all various rocks to completely understand the nature and characteristics of magmatic activity, which can provide basic information about the metallogenesis of Xiaojiashan tungsten deposit.

\footnotetext{
a Corresponding author : zhouyunfei0514@163.com
} 


\section{Geologic setting}

\subsection{Regional geology}

The Xiaojiashan tungsten deposit of Barkol, Xinjiang is located in the southern margin of the central East Junggar orogenic belt which belongs to the Junggar Plate. Stratigraphically, it belongs to Bogda Mountains Sub-district, North Tianshan Branch, Tianshan-Xing'an District. Strata in the mineralization belt are mainly Devonian and Quaternary. The regional strata mainly include Devonian, Carboniferous and Quaternary in area from the early to late stages, respectively. The Perhmian and Ordovician strata is distributed sporadically. The Devonian and Carboniferous strata is mainly include the intermediate-basic and intermediate-felsic volcanic rocks are the most widespread; The regional strata is mainly Permian and Ordovician strata, which are mainly clastic sedimentary rocks petrologically; the Quaternary strata is primarily alluvial and diluvial sediments, which are primarily made up of conglomerate, sandstone, siltstone, mudstone and loose windborne sediments[1].
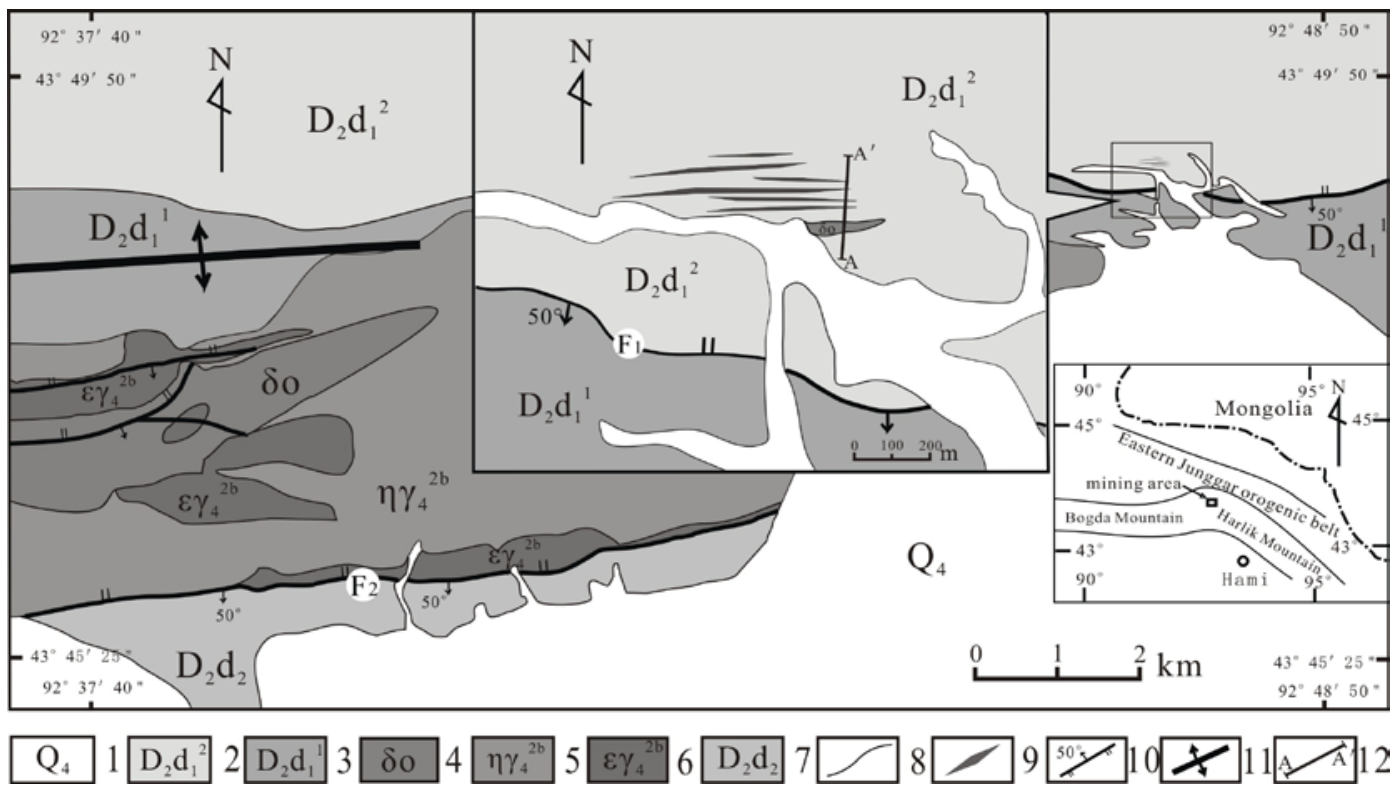

Figure 1. Sketch map of the Xiaojiashan region (After Sinotech Mineral Exploration Co.,Ltd., Beijing, China, 2013)

1- Quaternary system; 2- The second lithologic siction of the first sub-Formation of the Dananhu Formation; 3- The first lithologic siction of the first sub-Formation of Middle Devonian Dananhu Formation; 4- Gneissic quartz diorite; 5-Biotite monzonitic granite; 6- K-feldspar granite; 7- The second sub-Formation of Middle Devonian Dananhu Formation; 8- Geological boundary; 9- Tungsten quartz veinlet belts; 10 - Fault; 11 - Anticlinal axis; 12 - Geological section; $F_{1}$ - Northern fracture; $F_{2}$ Southern fracture; AA'- The measured profile (line237)

\subsection{Deposit Geology}

The strata in the Xiaojiashan Tungsten deposit area are mainly composed of First and Second SubFormation of Middle Devonian Dananhu Formation $\left(\mathrm{D}_{2} d_{1}, \mathrm{D}_{2} d_{1}\right)$, as well as Quaternary alluvial sediments $\left(\mathrm{Q}_{4}\right)$ (Fig. 1).

The first sub-Formation of Middle Devonian Dananhu Formation $\left(D_{2} d_{1}\right)$, mainly distributed in the north of mining area, comprise a north-dipping monoclinal structure. The first lithologic section of the first sub-Formation of Middle Devonian Dananhu Formation $\left(\mathrm{D}_{2} d_{1}{ }^{1}\right)$ is mainly composed of 
metamorphic crystal tuff, tuffaceous sandstone and a small amount of alternation diorite. The second lithologic section of the first sub-Formation of the Dananhu Formation $\left(\mathrm{D}_{2} d_{1}^{2}\right)$ is mainly metamorphic crystal tuff and a small amount of intrusive diorite veins.

The second sub-Formation of the Dananhu Formation $\left(D_{2} d_{2}\right)$, extending from east to west, is distributed in the south of mining area. The sub-formation lithology is mainly metamorphic crystal tuff, silty slate and a small amount of intrusive granite veins. The Quaternary sediments mainly covered in the south of mining area.

Tectonically, the deposit occurs in E-W striking Harlik anticlinorium. There are two faults $\left(\mathrm{F}_{1}\right.$ and $\mathrm{F}_{2}$ ) striking $\mathrm{E}-\mathrm{W}$ in the mine area, dipping to south with dip angle of $50^{\circ}$. The fault $\mathrm{F}_{1}$ occurs in the north of mining area, located between the first lithologic section and the second lithologic section of the first sub-Formation of Middle Devonian Dananhu Formation. It is easy to observe that quartz veins intercalated in rocks on both sides along the fault line. Silicification, pyritization, and chloritization are relatively developed in the deposit area, and there are a few sporadic potash feldspathization veinlets.

In the north-central part of mining area, there are quartz diorite, K-feldspar granite, monzonitic granite and a small amount of intermediate-acid granodiorite veins. Granite intrusion is controlled by the EW-trending fault. The contact metamorphism is developed.

Figure 2 is a typical geological profile, located in exploratory line 237, showing the characteristics of strata and intrusion in the north of Xiaojiashan Tungsten deposit area.
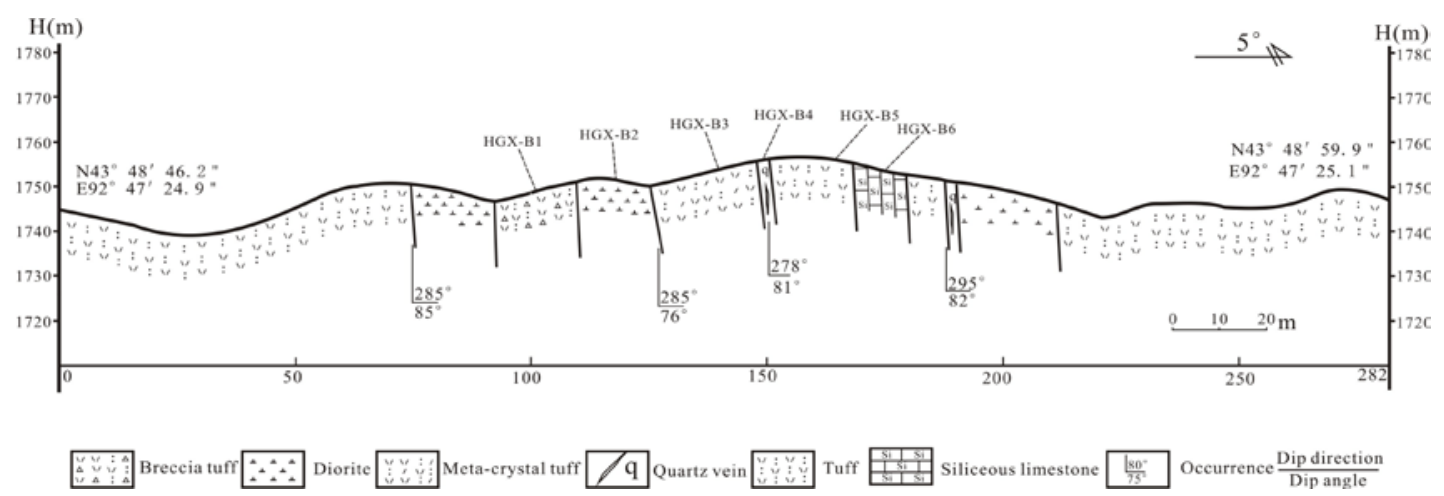

Figure 2. A geological profile of the Xiaojiashan tungsten deposit (Line 237)

B1- Breccia tuff; B2- Chloritization diorite; B3- Meta-crystal tuff; B4- Wolframite quartz vein; B5- Tuff; B6Siliceous limestone

\section{Mineralizing ore veins}

Exploratory trenchs reveal that tungsten mineralizing zones are mainly EW-extending, while wolframite quartz veins occur in S-N and E-W to land in the grid distribution. Two types of wolframite quartz veins can be identified: grey quartz vein $\left(\mathrm{Q}_{\mathrm{I}}\right)($ Fig. $3 \mathrm{~A})$ and white quartz vein $\left(\mathrm{Q}_{\mathrm{II}}\right)$ (Fig. 3B).

The main minerals in the ores are wolframite and quartz. Ore texture occurs as euhedral to subhedral, and metasomatic textures and fragmentation are commonly observed (Fig. 3C). The wolframite distribute in quartz veins as elongated, flaggy or disseminated. The gangue mineral is quartz which is of oily luster, and commonly occurring in limonitization, and they are dense block and closely associated with wolframite.

Wall rock alterations mainly include silicification, potassic feldspathization, as well as chloritization in the late stage. 


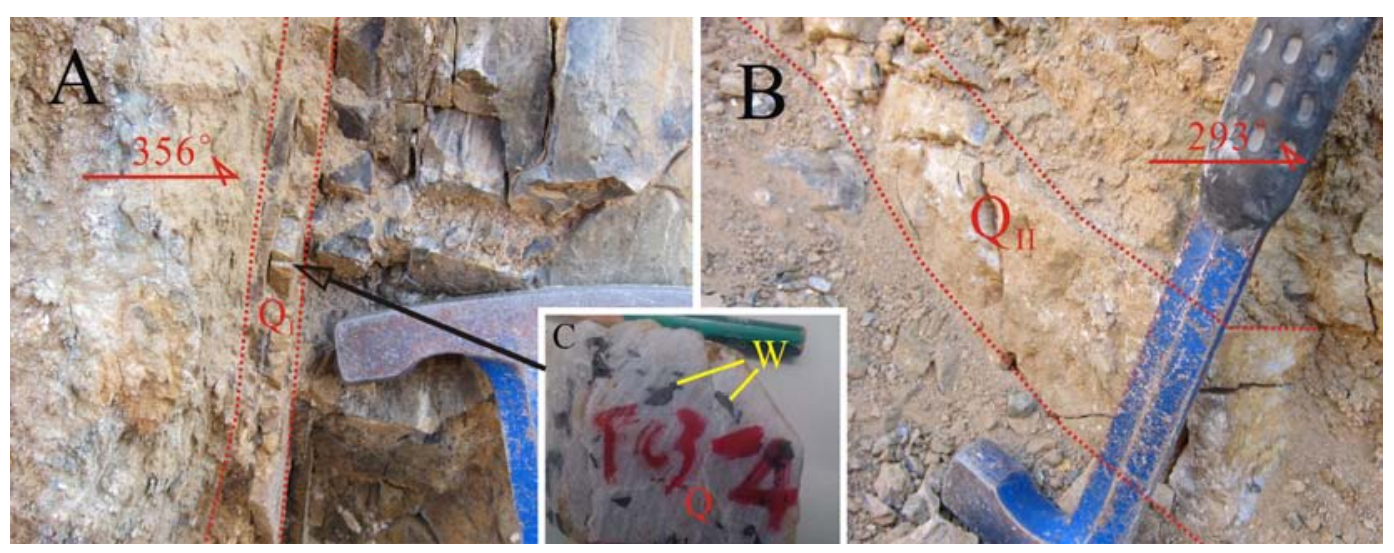

Figure 3. The photos showing wolframite-bearing quartz veins of the Xiaojiashan in field (A) EW-trending and S-leaning gray limonite wolframite quartz vein in groove, 83 meter distance in the south of TC3; (B) SN-trending and E-leaning white limonite wolframite quartz vein in groove, 56 meter distance in the south of TC2; (C) Ore hand specimens of wolframite(W) quartz veins(Q)

\section{Composition of ore fluids}

In order to understand ore-forming progress, the compositions of fluid inclusions were measured using Quadrupole Mass Spectrometry at the Institute of Geology and Geophysics, Chinese Academy of Sciences. Seven samples contain five quartz veins and two wolframites. The RG202 quadrupole mass spectrometer and HTC-6A type ion chromatograph are respectively used to measure the compositions of vapor and liquid phase of fluid inclusions. The test are processed with the sample vapor flow rate of $1.04 \mathrm{~L} / \mathrm{min}$, auxiliary vapor flow rate of $0.96 \mathrm{~L} / \mathrm{min}$, cooling air flow rate of $14.0 \mathrm{~L} / \mathrm{min}$, analysis room vacuum $6 \times 10^{-6} \mathrm{~Pa}$. Repeat measurement accuracy was $<5 \%$. The grain sizes of sample are $+60 \sim-40$ mesh. The weight of quartz samples are $2-5 \mathrm{~g}$, and wolframite sample have the weight of $0.5 \mathrm{~g}$. The purity single mineral sample is $>99 \%$.

Quadrupole mass spectrometer is producted by Japanese vacuum technology co., LTD production, SME voltage of $-1.22 \mathrm{~V}$, ionization ways is IE, ionization energy $50 \mathrm{eV}$, measurement speed is 50ms/amu [2,3]. RG202 quadrupole mass spectrometer was used to measure the compositions of vapor phase of fluid inclusions. The results are shown in table 1.

Table 1. Analysis results of quartz fluid inclusion vapor phase composition(mol\%)

\begin{tabular}{|c|c|c|c|c|c|c|c|c|}
\hline Sample no & $\mathbf{H}_{\mathbf{2}} \mathbf{O}$ & $\mathbf{N}_{\mathbf{2}}$ & $\mathbf{A r}$ & $\mathbf{C O}_{\mathbf{2}}$ & $\mathbf{C H}_{\mathbf{4}}$ & $\mathbf{C}_{\mathbf{2}} \mathbf{H}_{\mathbf{6}}$ & $\mathbf{H}_{\mathbf{2}} \mathbf{S}$ & $\mathbf{C O}_{\mathbf{2}} / \mathbf{H}_{\mathbf{2}} \mathbf{O}$ \\
\hline TC2-3 (Quartz) & 93.41 & 0.121 & 0.009 & 5.977 & 0.416 & 0.059 & - & 0.064 \\
\hline TC2-5 (Quartz) & 96.33 & 0.078 & 0.012 & 3.269 & 0.259 & 0.047 & - & 0.034 \\
\hline TC3-2B (Quartz) & 91.39 & 0.212 & 0.006 & 7.770 & 0.588 & 0.015 & - & 0.085 \\
\hline TC3-4 (Quartz) & 95.90 & - & 0.022 & 3.359 & 0.183 & 0.532 & - & 0.035 \\
\hline TC3-6 (Quartz) & 90.38 & 0.163 & 0.09 & 8.719 & 0.619 & 0.097 & - & 0.096 \\
\hline TC3-2B (Wolframite) & 89.63 & 0.184 & 0.0004 & 9.964 & 0.165 & - & - & 0.111 \\
\hline TC3-4 (Wolframite) & 91.65 & 0.221 & 0.022 & 7.723 & 0.363 & - & - & 0.084 \\
\hline Average & 92.67 & 0.163 & 0.011 & 6.683 & 0.371 & 0.150 & - & 0.072 \\
\hline
\end{tabular}

Test at the Institute of Geology and Geophysics, Chinese Academy of Sciences. “-” not detect

The vapor phase of fluid inclusion mainly contain $\mathrm{H}_{2} \mathrm{O}$ and $\mathrm{CO}_{2}$, followed by $\mathrm{N}_{2}, \mathrm{CH}_{4}$, as well as minor $\mathrm{Ar}, \mathrm{C}_{2} \mathrm{H}_{6}$. The molar concentration of $\mathrm{H}_{2} \mathrm{O}$ vary from $89.63 \%$ to $96.33 \%$, and the molar concentration of $\mathrm{CO}_{2}$ vary from $3.269 \%$ to $9.964 \%$. 
The liquid phase compositions of fluid inclusions from quartz veins are measured by HTC-6A type ion chromatograph. The results are shown in table 2.

Table 2. Analysis results of quartz fluid inclusion liquid phase composition $(\mu \mathrm{g} / \mathrm{g})$

\begin{tabular}{|c|c|c|c|c|c|c|c|c|}
\hline Sample no & $\mathbf{F}^{-}$ & $\mathbf{C l}^{-}$ & $\mathbf{S O}_{\mathbf{4}}{ }^{2-}$ & $\mathbf{N a}^{+}$ & $\mathbf{K}^{+}$ & $\mathbf{M g}^{2+}$ & $\mathbf{C a}^{2+}$ & $\mathbf{N a}^{+} / \mathbf{C a}^{2+}$ \\
\hline TC2-3 (Quartz) & - & 53.6 & - & 38.5 & - & - & 1.57 & 24.522 \\
\hline TC2-5 (Quartz) & - & 54.5 & - & 40.2 & - & - & 1.15 & 34.957 \\
\hline TC3-2B (Quartz) & - & 58.0 & - & 42.0 & - & - & 3.60 & 11.667 \\
\hline TC3-4 (Quartz) & - & 51.4 & - & 36.7 & - & - & 0.627 & 58.533 \\
\hline TC3-6 (Quartz) & - & 65.5 & - & 48.0 & - & - & 3.09 & 15.534 \\
\hline
\end{tabular}

Test at the Institute of Geology and Geophysics, Chinese Academy of Sciences. “-” not detect

The liquid phase compositions of fluid inclusions mainly contain $\mathrm{Cl}^{-}, \mathrm{Na}^{+}$, followed by $\mathrm{Ca}^{2+}$. The ion number ratios of $\mathrm{Na}^{+} / \mathrm{Ca}^{2+}$ vary from 11.667 to 58.533. The contents of $\mathrm{Cl}^{-}, \mathrm{Na}^{+}$are far more than other ions, indicating that the salt compounds in ore-forming fluid are mainly $\mathrm{NaCl}$, as well as a spot of Ca-compounds.

\section{Discussion}

Quadrupole mass spectrometry reveals that fluid inclusions contain major vapor phase contents of $\mathrm{CO}_{2}, \mathrm{H}_{2} \mathrm{O}$. In addition, there is a little variable component of $\mathrm{Ar}, \mathrm{C}_{2} \mathrm{H}_{6}$ in vapor phase. Meanwhile, fluid inclusions contain major liquid phase contents of $\mathrm{Cl}^{-}, \mathrm{Na}^{+}$and a little variable positive ion component of $\mathrm{Ca}^{2+}$. For the quartz veins containing $\mathrm{CO}_{2}$ component inclusions in the tungsten mining area, some researchers suggest that the precipitation of $\mathrm{CH}_{4}$ components could cause an unmixing of $\mathrm{NaCl}-\mathrm{H}_{2} \mathrm{O}-\mathrm{CO}_{2}$ fluids in vein quartz at the bottom of tungsten deposit[4]. Liquid unmixing plays an important role in tungsten precipitate from hydrotherm[5].

The late stage medium-low temperature fluid activities indicate the natural cooling process of fluids. The natural cooling process of the fluid system plays as an important role in the hydrothermal decomposition and precipitation of tungsten clathrate[6]. In the major tungsten ore-forming stage, magmatic hydrothermal fluids are driven under temperature and pressure differences. Transporting fracture structures and ore-forming fluids were cooled during tungsten element migration. Because the $\mathrm{NaCl}-\mathrm{H}_{2} \mathrm{O}-\mathrm{CO}_{2}$ fluid in the quartz vein was unmixing, the tungsten clathrate was decomposed and precipitated.

\section{Summary}

The mineralizing belt of the Xiaojiashan tungsten mining area occur as East-West trending zone, which are characterized by tungsten-bearing quartz vein system. Ore minerals are primarily composed of quartz and wolframite. Two types of tungsten-bearing quartz veins can be found in the deposit, including grey wolframite-quartz vein and white quartz vein.

Quadrupole mass spectrometry reveals that fluid inclusions contain major vapor phase contents of $\mathrm{CO}_{2}, \mathrm{H}_{2} \mathrm{O}$. Meanwhile, fluid inclusions contain major liquid phase contents of $\mathrm{Cl}^{-}, \mathrm{Na}^{+}$. It can be speculated that ore-forming fluid of the Xiaojiashan wolframite deposit is characterized by a $\mathrm{CO}_{2}$-rich, low salinity, and $\mathrm{H}_{2} \mathrm{O}-\mathrm{CO}_{2}-\mathrm{NaCl}$ system.

The ore-forming fluids of the tungsten deposit had a source of magmatic water, and mixing of magmatic and meteoric water happened in the late stage. During ore-forming process, magmatic water had separated from magmatic intrusion and brought tungsten complex to a portion where tungstenbearing ores could be mineralized. 


\section{Acknowledgement}

This paper is funded by National Nature Science Foundation of China (41372096). Thanks are due to geological engineer Shan LH of the mineral exploration co., LTD. for providing help in the field. Thanks the researchers from the Test Centre of CNNC Beijing Research Institute of Uranium Geology for their support and assistance with this paper.

\section{References}

1. F.S.Lou, C.H.Tang, Xinjiang Geology, 13 (1): 67-76 (1995)

2. H. P. Zhu, L. J. Wang, Science in China, D31(7): 586-590 (2000)

3. H. P. Zhu, L. J. Wang, J. M. Liu, Acta Petrologica Sinica, 19 (2): 314-318 (2003)

4. F. J. Rios, R. N. Villas, K. Fuzikawa, Journal of South American Earth Sciences, 15: 790-794 (2003)

5. C. S. So, S. T. Yun, Econ. Geol, 89: 246-267 (1994)

6. M. Giamello, G. Protano, F. Riccobono, G. Sabatini, Eur. J. Mineral, 4: 1079-1084 (1992) 